ISSN: 2162-3104 Print/ ISSN: 2166-3750 Online

Volume 8, Issue 1 (2018), pp. 38-65

(C) Journal of International Students

http://jistudents.org/

doi: 10.5281/zenodo.1101030

\title{
Destination Motivation, Cultural Orientation, and Adaptation: International Students' Destination-Loyalty Intention
}

\author{
Nor Lelawati Jamaludin \\ Universiti Teknologi MARA, Malaysia \\ University of Bergen, Norway \\ David Lackland Sam \\ Gro Mjeldheim Sandal \\ University of Bergen, Norway
}

\begin{abstract}
This study aims to understand factors predicting destination-loyalty intention in international education. A sample of 378 long-term $(n=195)$ and short-term ( $n=183)$ international students participated in the study carried out in 2014 through an on-line survey at the University of Bergen, Norway. Using a series of hierarchical regression analyses, the researchers found that among short-term students, destination motivation (pull), orientation to mainstream and heritage culture together with psychological adaptations were the most important variables influencing their decision to revisit and to recommend the destination to others. Among long-term students, the same variables with the exception of psychological adaptation in addition to sociocultural adaptation were the significant predictors of destinationloyalty intention. This study discusses the results from a social, psychological and international education perspective as well as their implications for destination management.
\end{abstract}

Keywords: destination-loyalty intention, mainstream culture, psychological adaptation, pull motivation, push motivation, sociocultural adaptation 
Imagine the following scenario: Someone has just come back from studying abroad at a well-known education destination. In retrospect, he or she emphasizes that the destination met all the anticipated criteria, and that he or she had a wonderful experience, is satisfied and willing to revisit and recommend the destination to others. At the same time, he or she comments that there were other international students who preferred to stay at the students' hostel, showing little or no interest in exploring the destinations. They were neither happy nor satisfied with the overall experience with the locals at the destination because their initial expectations of the destination were not met. As a result, they disliked the place and were not interested in sharing their experiences with others. Neither were they interested in recommending the place to others.

This hypothetical scenario is a reflection of how the individual's decision prior to international education and experience of local host culture plays an important role in determining destination-loyalty intention. Grounded in the acculturation framework developed by Berry and his associates (Berry, 1990, 1992; Berry, 1997; Berry, 2005; Berry, Kim, Minde, \& Mok, 1987; Berry, Kim, Power, Young, \& Bujaki, 1989) and other relevant literature, the researchers seek to understand how motivation to study abroad may influence international students' motivation to revisit and later recommend the destinations to others. Specifically, this research examines the independent contributions made by motivation to study abroad, orientation to mainstream culture at the destination, orientation to heritage culture, and sociocultural and psychological adaptations at the destination in predicting destination-loyalty intention. This research is in response to the claim by Ryan and Glendon (1998) that research has paid too little attention to the psychological aspects of the experience of international education. This research is also in response to the call by Yuksel, Yuksel, and Bilim (2010) for exploring the relationship between destination loyalty and psychological factors. To date, knowledge on how and why psychological factors may lead to destination-loyalty intention is very limited.

As part of internationalization of higher education, colleges and universities continuously recruit and accept international students (Guo \& Chase, 2011). In some countries, exchange study and educational travel has become a stable and ongoing industry that outperforms leisure and business tourism in terms of its annual growth (Lesjak, Juvan, Ineson, Yap, \& Axelsson, 2015).

International students serve as "ambassadors" of their own country during their overseas sojourn (Jamaludin, Sam, Sandal, \& Adam, 2016a). 
Jamaludin and colleagues have also pointed out that upon returning home, international students take on a reverse ambassadors' role as representatives of the countries where they studied. Based on their sojourned experiences, they can encourage (or discourage) people in their social network to visit their previous international education destination. This latter role is linked to the students' loyalty to the country in which they studied. This is the focus of this study.

Destination-loyalty intention as used in this study refers to international students' intentions to revisit and recommend the destination to people in their home country (Oppermann, 2000; Yoon \& Uysal, 2005). The objective of this study was to investigate the extent to which destinationloyalty intentions could be predicted by the students' destination motivation (pull and push), their orientations to the mainstream culture of the society they studied, vis-à-vis their own heritage culture, together with their psychological and sociocultural adaptation while studying abroad.

\section{LITERATURE REVIEW}

\section{Projecting the Differences for International Students}

To understand destination-loyalty intention, the present study distinguished between two types of students: those on long-term programs versus those on short-term programs. In line with this, it is known that individuals' motivation for pursuing exchange programs for a semester or a year are different from those pursuing a degree that stretches over a number of years (Jamaludin et al., 2016a).

The main motivation of short term students, according to Massey and Burrow (2012), is to experience a new cross-cultural learning environment, followed by a specific academic opportunity and a unique social experience. Just like their short-term peers, long-term students also have as their prime motive a cross-cultural experience (Brewer, 1983; Carlson \& Widaman, 1988; Sánchez, Fornerino, \& Zhang, 2006), in addition to academic and/or foreign language development (Caudery, Petersen, \& Shaw, 2008).

Despite the similarities between the two groups of exchange students, there are more differences between the two than it may first seem to appear. Studying abroad has a more significant and enduring impact on long-term students than their short-term counterparts (Dwyer, 2004). Dwyer also pointed out that study abroad has a significant impact on students in the areas of continued language use, academic attainment measures, 
intercultural and personal development, and career choices. In addition, these factors are more likely to hold true for long-term students than for short-term students. Based on these subtle differences between the two groups of students, the researchers assume that they will differentially impact on their destination loyalty intentions, and further explore this assumption in the study.

There were also differences among international students with regards to cultural orientation. Pitts (2009) suggested that short-term visits do not offer the same level of cultural immersion and opportunities for intercultural growth compared to long-term program visits. This makes us believe that international students on short-term and long-term programs have differential destination-loyalty intentions.

With regard to adaptation, acculturation researchers make a distinction between psychological and sociocultural adaptation (Schachner, Schiller, Van de Vijver, \& Noack, 2014). Psychological adaptation outcomes include well-being, life satisfaction, and mental health, whereas sociocultural adaptation outcomes refer to an individual's competence in mastering daily life in a particular cultural context (Ward, 2001). In this study, life satisfaction was used as an indicator of psychological adaptation in this study was measured by life satisfaction (see Berry, Phinney, Sam, \& Vedder, 2006). Life satisfaction is the global evaluation of a person's quality of life based on the person's own chosen criteria (Shin \& Johnson, 1978). Likewise, other studies indicate that people who are satisfied with life tend to be more successful and socially active (Diener, Kanazawa, Suh, \& Oishi, 2015; Otrachshenko \& Popova, 2014).

Additionally, empirical evidence by Graham and Markowitz (2011) and Jamaludin, Sam, Sandal, and Adam (2016b) confirmed that life satisfaction influences an individual's intention to stay at a destination. Finally, positive interactions with members of the host culture are likely to improve one's feelings of well being and satisfaction (Sam \& Berry, 2010). Sociocultural adaptation is relevant to performing daily tasks in the host culture (Ward, 1996; Ward \& Kennedy, 1999). This distinction can also be applied to the context of education adjustment outcomes (Berry et al., 2006). Sociocultural adaptation in our context refers to culture learning and acquisition of social skills relevant for the mainstream culture at the destination (Berry \& Sam, 1997; Ward \& Kennedy, 1999). Sociocultural adaptation in this study focuses on how international students acquire social and cultural that might facilitate social integration knowledge (Hirai, Frazier, \& Syed, 2015) which may be important in influencing their destination-loyalty intention. 


\section{Potential Predictors of Destination-Loyalty Intentions}

Behavioral intention is the probability or possibility of person engaging in a specified behavior, and can also reflect the willingness of the individual to perform a behavior ( $\mathrm{Lu}, \mathrm{Yeh}, \&$ Chen, 2016). With regard to destination-loyalty intention, researchers have measured tourists' behavioral intentions based on the belief that behavioral intentions are sufficient to capture the dynamics of the loyalty phenomenon (i.e., Chen \& Tsai, 2007; Lee, 2009). Moreover, other researchers have suggested that tourists are likely to develop emotional attachment to their destinations, and this attachment can be an important antecedent and a good indicator of tourists' loyalty to a destination (George \& George, 2012; Lee, Backman, \& Backman, 1987).

Although studies on destination-loyalty intentions abound, there is a dearth of research within the context of international education. Studies have shown that educational experiences of international students impact their loyalty intention to the destination (Jamaludin et al., 2016a; 2016b). They suggest that international students who have a positive experience and strong relationship with the host society will be more likely to return to the host destination or recommend it to others. However, to date, consensus on what the most important factors are remains divided. This research aims to fill this gap.

\section{Destination Motivation}

Prior studies have examined the phenomenon of students' educational motivation from the self-determination theory perspective. Selfdetermination theory looked into a critical issue in the effects of goal pursuit and attainment concerns the degree to which people are able to satisfy their basic psychological needs as they pursue and attain their valued outcomes (Deci \& Ryan, 2000). These have provided some insights on educational motivation (i.e., Hill, 2013; Kember, Hong, \& Ho, 2008).

Building on this, the present study seeks to determine the nature or the contents of the motivation (push and pull) framework of student mobility (González, Mesanza, \& Mariel, 2011; Mazzarol \& Soutar, 2002). "Push" and "pull" motivations proposed by Dann (1977) and Dann (1981) have been one of the most widely accepted theories in the travel motivation literature (Jang \& Cai, 2002; Yoon \& Uysal, 2005).

"Push" motivations refer to elements that operate in the home country of the student, which stimulate or literally "push" the individual to 
study abroad (González et al., 2011). "Pull" factors refer to elements of a country that "pull" a student to study abroad (González et al., 2011) and operate within the source country to initiate a student's decision to undertake an international study there (Mazzarol \& Soutar, 2002). According to Lesjak et al. (2015), the combination of push and pull factors determines a student's decision to study abroad and later influences his/her destination choice. Likewise, other researchers also claim that there is a strong link between destination motivation and destination choices or loyalty (Bieger \& Laesser, 2002; Wang \& Leou, 2015).

With regards to international students' motivation, Mazzarol and Soutar (2002) found that economic and social forces in the home country serve as the main "push" factor. However, they found that the decision to "pull" students abroad will depend on a variety of factors such as awareness and reputation of the host country and institutions, personal recommendations and word-of-mouth referrals.

Referring to the push-pull approach by Mazzarol and Soutar (2002), other studies have suggested that students' travel decisions may be pushed by intangible factors (e.g. exploration) and pulled by tangible factors such as natural attractions, entertainment and events, and night life (Kim, 2008; Kim \& Lee, 2002; Sirakaya, Uysal, \& Yoshioka, 2003). In addition, safe and secure environments, standard (high or low cost) of living and geographical proximity to the home country, are found to influence Asian students' destination choices. Mazzarol and Soutar (2002) found that American students cite knowledge of foreign language as the prime factor influencing their intentions to study abroad. Younger travelers (under 26) place more emphasis on social contact and excitement, while the older group seek more individualized and less extreme experiences (Lesjak et al., 2015).

Moreover, research on students' travel motivation identified that proximity of the host country to, and its cultural and social ties with, the country of origin are important factors that influence students' choices of study locations (i.e., Lesjak et al., 2015). In comparison, other studies found that awareness of information on the host country, personal background and financial situation, the comparability of the higher education system in the host country, and administrative and funding conditions are obstacles to participation, and do have an impact on destination choice motives (SoutoOtero, Huisman, Beerkens, de Wit, \& VujiĆ, 2013).

In summary, while literature has shown numerous links between motivation-destination choices and loyalty of international students, consensus on how motivation may be related to destination-loyalty intention among short-term and long-term international students' remains divided. 
Thus, the researchers further explored how push and pull motivation factors may affect their destination-loyalty intention.

\section{Orientation to Mainstream Culture and Heritage Culture}

Cultural orientation refers broadly to an individual's orientations toward mainstream culture and their ethnic culture and has often been indexed by their endorsement of particular cultural values (Neblett, Rivas-Drake, \& Umaña-Taylor, 2012). Neblett and colleagues suggested that such orientations are frequently understood within discussions of acculturation and enculturation, which characterize orientations toward mainstream and ethnic culture, respectively. Acculturation is a multifaceted process of change occurring when at least two cultures come into continuous contact with each other (Berry \& Sam, 2003). Although acculturation models focus on orientations to one's heritage culture and the culture of the society of settlement, these two dimensions are seen as independent of each other (Berry, 1997; Ryder, Alden, \& Paulhus, 2000).

Contact and social ties with the host nation's residents have been shown to facilitate and enhance international students' experience and adjustment (Campbell, 2011; Furnham \& Bochner, 1982; Jamaludin et al., 2016a; Shigaki \& Smith, 1997; Stone, 2000). The more assimilated individuals are towards a host country's culture, the greater the progression in taking up the attitudes and values of the host society (Faber, O'Guinn, \& Meyer, 1987). According to Berry (1997), assimilation happens when individuals do not wish to maintain their heritage culture and primarily interact with mainstream culture. Contrariwise, integration happens to those who, for various reasons desire to maintain their heritage culture while adapting and adopting the mainstream culture (Berry, 1997). International students who demonstrate assimilation or integration, may thus be considered well-adjusted, which arguably should be more likely to remain and have a sense of positive integration or assimilation, which arguably should strengthen their educational goals, commitment, and loyalty to the institution (Jamaludin et al., 2016a; Zea, Reisen, Beil, \& Caplan, 1997).

On the other hand, home culture priming or heritage-culture cues (i.e. cultural icons such as symbols, architecture) may disrupt students' performance abroad, such as their motivation for learning and speaking the local language (Zhang \& Dixon, 2003). Further, Berry (2005) suggested that separation from the host culture/s is the preferred strategy of individuals who place high value on holding on to their heritage culture, and low value on acquiring the host culture. These individuals choose the separation 
alternative. Additionally, he suggested that individuals who place a value on holding on to their heritage culture also tend to turn their back on involvement with other cultural groups while holding on to their heritage culture. Therefore, the researchers assume that this will have a negative relationship with their loyalty intention to a destination. Accordingly, Yavas (1990) noted that Saudi tourists were concerned about the West's image and preferred to visit Muslim countries, suggesting that orientation to heritage culture does play a role in influencing intention. However, the study on second generation Korean immigrants in America by Lee (2002) suggested that Korean immigrants cope with this conflict by finding a balance, by adjusting to the American ways without turning their backs completely on their ethnic background. He further added that for such an ideal identity to succeed, the wider society must recognize the presence and needs of such culturally mixed identities, and encourage the maintenance of ethnic identity instead of enforcing conformity to the home culture ways.

Taking into consideration the orientation to heritage culturedestination-loyalty intention perspectives and observing the literature over time, it appears that they are not completely exclusive. Hence, the researchers further explored how orientation to heritage culture may affect students' destination-loyalty intention.

Berry (1997) pointed out that factors such as destination motivation need to be studied as a basis for understanding the degree of voluntariness in the acculturating individuals. Assuming that that this will influence the student's adaptation, it is reasonable to suggest that a better understanding of cultural orientation for international students will be vital for all stakeholders.

\section{Sociocultural and Psychological Adaptation at the Destination Site}

All students who embark on an education journey in a country other than that of their origin are expected to adjust to the new environment. This may be challenging, as they will have to cope with a dual challenge (Wang \& Hannes, 2014). Wang and colleague pointed out that international students, like all first-year university students, need to adapt to academic life, and in addition must also deal with the acculturation stress encountered by every sojourner (Toyokawa \& Toyokawa, 2002; Wang \& Mallinckrodt, 2006).

Additionally, other studies pointed out that as intercultural contact continues to increase on college campuses, there is a continuing greater need to develop cultural competency and adaptation (Dorozhkin \& Mazitova, 
2008; Mahmood, 2014). In line with this, Ajzen and Madden (1986) suggest that the evaluation of an act (in this study, adaptation) is particularly useful in predicting intentions.

Sociocultural adaptation influences psychological adaptation (Vedder, van de Vijver, \& Liebkind, 2006). Furthermore, psychological adaptation is known to influence the individual's intention to stay at a destination (Graham \& Markowitz, 2011; Soderlund \& Ohman, 2003). They suggested that the chance of relocating is high when people are dissatisfied with their home country. Further, a study by Jamaludin et al. (2016b) on life satisfaction as one component of subjective well-being confirmed its positive associations towards destination-loyalty intention. Sociocultural and psychological adaptations are interrelated, and positive interactions with members of the host culture are likely to improve one's feelings of wellbeing and satisfaction (Sam \& Berry, 2010). It is, however, unclear whether sociocultural adaptation influences destination-loyalty intention or not and therefore the researchers try to fill this gap by examining whether sociocultural adaptation differentially influences destination-loyalty intention for students on short versus long-term programs.

Using life satisfaction as an indicator of psychological adaptation, the researchers explore how it may influence international students' intention to commit to a destination. The researchers assume that the international student's role becomes increasingly crucial for the success of international education. Based on the general literature on the studied relations (Graham \& Markowitz, 2011; Otrachshenko \& Popova, 2014; Soderlund \& Ohman, 2003), the researchers expect international students' psychological adaptation will increase their attachment to the destination where they studied.

\section{Hypotheses}

Based on the literature, the following hypotheses were tested:

1. Destination motivation (push) will have weaker positive relationship with destination-loyalty intention for (H1a) short-term than (H1b) long-term students.

2. Destination motivation (pull) will have weaker positive relationship with destination-loyalty intention for $(\mathrm{H} 2 \mathrm{a})$ short-term than $(\mathrm{H} 2 \mathrm{~b})$ long-term students. 
3. Orientation to heritage culture will have weaker negative relationship with destination-loyalty intention for $(\mathrm{H} 3 \mathrm{a})$ short-term students than $(\mathrm{H} 3 \mathrm{~b})$ long-term students.

4. Orientation to mainstream culture will have weaker positive relationship with destination-loyalty intention for (H4a) short-term than (H4b) long-term students.

5. Sociocultural adaptation will have weaker positive relationship with destination-loyalty intention for (H5a) short-term than (H5b) longterm students.

6. Psychological adaptation will have weaker positive relationship with destination-loyalty intention for (H6a) short-term than (H6b) long-term students.

\section{RESEARCH METHOD}

\section{Pilot Test of the Instrument}

A group of 30 international students from various countries were selected via convenience sampling to pilot test the instrument. Testing the instrument was limited to the face validity (clarity of instruction and questions) considering the fact that the measurement structure and language used as a means to measure these predictors was rigorously tested by a significant number of researchers mentioned in the literature review. The respondents were presented with the actual survey questions, and their time to respond to the instrument ranged from 5 to $10 \mathrm{~min}$. During the pilot test, none of the respondents requested verbal assistance and they answered all the questions. In general, the respondents participating in this pilot study reported that the instrument was clear in both its instructions and the questions it contained.

\section{Data Collection}

This study was reviewed and approved by the Norwegian Centre for Research Data. All registered international students at the University of Bergen were eligible to participate in the study. These students were contacted to participate via an email from the International Students' Office at the University of Bergen through its database. Study data were obtained using a questionnaire administered in English, asking students to provide information on different aspects of their lives, experiences and demographic background. 


\section{Sampling Design}

The sample was drawn from the population of international students registered at the University of Bergen. In order to minimize sampling bias, a convenience sampling was drawn from the list of students, from January 4, 2014 until June 30, 2014. To maximize the responses' generalizability, only groups where the target respondents were international students were selected.

After the inspection and clean-up of the data, a total of 378 $(34.87 \%)$ cases were used for the final analysis. The international student population included those on short-term programs lasting about one semester as well as those pursuing degrees. Table 1 shows the demographic profile of the respondents separated into long-term $(n=195)$ vs. short-term $(n=183)$. In this study, short-term students comprise those who came to study for periods of less than 12 months. They were all from Europe $(100 \%)$. Long-term students (studied at the host destination for 12 months and longer/full degree) came from a number of different countries; the majority (more than 60\%) came from Africa and Asia. In terms of gender distribution, and among long-term students, there was an even split between female and male students: 50.3\% females vs. $49.7 \%$ males. Among shortterm students however, there was a higher proportion of females $(66.7 \%)$ relative to males $(33.3 \%)$. For all groups, the majority (more than 50\%) was between 20 to 30 years old.

\section{Measurement of the Variables}

All items except for sociocultural adaptation were answered on 5point scales $(1=$ strongly disagree to $5=$ strongly agree $)$ and the overall score was calculated by taking the mean score of the items.

\section{Destination-Loyalty Intention}

Following Oppermann (2000), three indicators were used to measure tourist destination-loyalty intention as the ultimate dependent construct. Sample of the questions were: "After I have completed my course/study, I will travel to Bergen if my financial position permits it" and "I will recommend Bergen to my friends/relatives as a vacation destination to visit." 
Table 1. Demographic profile of respondents.

\begin{tabular}{|c|c|c|}
\hline Program demographics & Frequency & Percent \\
\hline \multicolumn{3}{|l|}{ Short-term } \\
\hline \multicolumn{3}{|l|}{ Gender } \\
\hline Female & 122 & 66.7 \\
\hline Male & 61 & 33.3 \\
\hline Total & 183 & 100.0 \\
\hline \multicolumn{3}{|l|}{ Age } \\
\hline $20-30$ & 168 & 91.8 \\
\hline $31-40$ & 14 & 7.7 \\
\hline $41-50$ & 1 & 0.5 \\
\hline Total & 183 & 100.0 \\
\hline \multicolumn{3}{|l|}{ Continent } \\
\hline Europe & 183 & 100.0 \\
\hline Total & 183 & 100.0 \\
\hline \multicolumn{3}{|l|}{ Long-term } \\
\hline \multicolumn{3}{|l|}{ Gender } \\
\hline Female & 98 & 50.3 \\
\hline Male & 97 & 49.7 \\
\hline Total & 195 & 100.0 \\
\hline \multicolumn{3}{|l|}{ Age } \\
\hline $20-30$ & 115 & 59.0 \\
\hline $31-40$ & 61 & 31.3 \\
\hline $41-50$ & 18 & 9.2 \\
\hline $50+$ & 1 & 0.5 \\
\hline Total & 195 & 100.0 \\
\hline \multicolumn{3}{|l|}{ Continent } \\
\hline Africa & 61 & 31.3 \\
\hline Asia & 60 & 30.8 \\
\hline Europe & 30 & 15.4 \\
\hline North America & 15 & 7.7 \\
\hline Oceania & 13 & 6.7 \\
\hline South America & 16 & 8.2 \\
\hline Total & 195 & 100.0 \\
\hline
\end{tabular}




\section{Destination Motivation}

In this study, destination motivation was measured using the international students push and pull motivation scale by Mazzarol and Soutar (2002). After a pilot test, the relevant items from the instruments (20 items) measuring push (6) and pull motivation (14) were selected. Example of an item of the push motivation factor is "I plan to immigrate in the future." For pull motivation, factor such as "A foreign university degree will open good employment opportunities for me" was included.

\section{Orientation to Mainstream Culture and Heritage Culture}

Orientation to mainstream and heritage culture was measured with the Vancouver Index of Acculturation (VIA) by Ryder et al. (2000). The VIA consists of two categories: orientation to mainstream culture and orientation to heritage culture. The two categories are measured by 10 items each. Example of an item in the scales is: "I often participate in mainstream Norwegian cultural traditions."

\section{Sociocultural Adaptation}

This was assessed using 23 of the 40 items proposed by Ward and Kennedy (1999). These 23 items were deemed more relevant for international students. Examples of the items were: "To what extent have you experienced difficulties in the following areas while staying in Norway: (1) Making friends and (2) Using public transport, etc." Average scores of the items were used to measure the overall sociocultural adaptation level. Higher values obtained in the scale indicated greater difficulty in sociocultural adaptation. However, for easier interpretation of the results, the researchers reversed scores on the items so that higher scores indicated better sociocultural adaptation.

\section{Psychological Adaptation}

Psychological adaptation (i.e., life satisfaction) was assessed using the 5-item scale by Diener, Emmons, Larsen, and Griffin (1985). Sample questions are: "In most ways my life is close to my ideal" and "The conditions of my life are excellent." 


\section{RESULTS}

To examine the unique contribution of all the independent variables to destination-loyalty intention, a hierarchical multiple regression analysis was performed. In hierarchical multiple regression analysis, the researchers determined the order that variables are entered into the regression equation based on the relevant literature. Prior to conducting hierarchical multiple regressions, the relevant assumptions of this statistical analysis were tested. Firstly, the sample sizes for long-term $(N=195)$ and short-term $(N=183)$ students were deemed adequate given six independent variables to be included in the analysis (Tabachnick \& Fidell, 2001). The assumption of singularity was also met among the independent variables. An examination of the correlation matrixed (see Table 2) indicated that the variables were not highly correlated. The internal consistencies of the various indices were found to be acceptable, with Cronbach alpha values ranging from .60 to .91 .

Next, results in Table 3 shows that the assumptions of normality were also all satisfied (Hair, Black, Babin, \& Anderson, 2010; Pallant, 2013). Moreover, the Durbin-Watson values showed no autocorrelation in the regression models.

The collinearity statistics (i.e. Tolerance and VIF) were all within accepted limits, indicating that the assumption of no multicollinearity was deemed to have been met (Hair et al., 2010). An examination of the Mahalanobis distance scores identified two outliers in the short-term student group and one outlier in the long-term student group. These outliers were deleted.

A three-stage hierarchical multiple regression was conducted separately for the two groups (short-term and long-term students) with destination-loyalty intention as the dependent variable (see Table 3). The relationship variables were entered in this order as it seemed chronologically plausible based on the literature grounded in Berry's acculturation framework (Berry, 1997).

For short-term students, gender and age did not contribute significantly to the regression model, $F(2,180)=1.83, p>.001$; these variables accounted for only $2.0 \%$ of the variation in destination-loyalty intention. Introducing destination motivation (push and pull) to the regression model explained an additional $3.1 \%$ of variation in destinationloyalty intention, and this change in $R^{2}$ was significant, $F(4,178)=2.37, p<$ .05 . Finally, adding orientation to mainstream and orientation to heritage culture, psychological adaptation and sociocultural adaptation in stage three, 
explained a total of $19.7 \%$ of the variation in destination-loyalty intention; this change in $R^{2}$ was also significant, $F(8,174)=7.16, p<.001$.

Just as for short-term students, age and gender did not contribute significantly to the regression model, $F(2,192)=0.134, p>.001$ for longterm students. The two variables accounted for only $1.0 \%$ of the variation in destination-loyalty intention. Introducing destination motivation (push and pull) to the regression model explained an additional $8.5 \%$ of the variation in destination-loyalty intention, and this change in $R^{2}$ was significant, $F(4$, $190)=4.44, p<.01$. Finally, adding orientation to mainstream and orientation to heritage culture, psychological adaptation and sociocultural adaptation in stage three, explained a total of $16.5 \%$ of the variation in destination-loyalty intention; this change in $R^{2}$ was also significant, $F(8,186)$ $=7.78, p<.001$.

Table 2: Correlation for the Variables

\begin{tabular}{|c|c|c|c|c|c|c|c|c|c|c|c|c|}
\hline & 1 & 2 & 3 & 4 & 5 & 6 & 7 & 8 & 9 & Mean & $\mathrm{SD}$ & $\begin{array}{c}\text { Cronbach } \\
\text { Alpha }\end{array}$ \\
\hline Short-term & - & & & & & & & & & 133 & 473 & \\
\hline $\begin{array}{l}\text { 1. Gender } \\
\text { 2. Age }\end{array}$ & .064 & - & & & & & & & & $\begin{array}{l}1.33 \\
1.09\end{array}$ & $\begin{array}{r}.4 / 3 \\
302\end{array}$ & \\
\hline $\begin{array}{l}\text { 3. Destination-loyalty } \\
\text { intention }\end{array}$ & -.132 & .040 & - & & & & & & & 4.25 & .605 & .70 \\
\hline $\begin{array}{l}\text { 4. Orientation to } \\
\text { heritage culture }\end{array}$ & .024 & .007 & .037 & - & & & & & & 3.75 & .439 & .72 \\
\hline $\begin{array}{l}\text { 5. Orientation to } \\
\text { mainstream culture }\end{array}$ & .025 & .042 & $.391^{* *}$ & $.505^{\circ *}$ & - & & & & & 3.79 & .383 & .70 \\
\hline $\begin{array}{l}\text { 6. Psychological } \\
\text { adaptation }\end{array}$ & -.112 & .059 & $.259^{* *}$ & $.237^{* *}$ & $.326^{* *}$ & - & & & & 3.54 & .683 & .79 \\
\hline $\begin{array}{l}\text { 7. Sociocultural } \\
\text { adaptation }\end{array}$ & -.008 & .033 & .053 & -.048 & .049 & -.060 & - & & & 3.37 & .657 & .91 \\
\hline $\begin{array}{l}\text { 8. Destination } \\
\text { motivation (Push) }\end{array}$ & -.113 & .041 & .102 & .115 & $.158^{*}$ & .003 & -.086 & - & & 3.36 & .786 & .60 \\
\hline $\begin{array}{l}\text { 9. Destination } \\
\text { motivation (Pull) }\end{array}$ & -.057 & .093 & $.186^{\circ}$ & $.176^{\circ}$ & $.191^{* *}$ & .022 & $-.212^{* *}$ & $.478^{* *}$ & - & 2.99 & .551 & .75 \\
\hline \multicolumn{13}{|l|}{ Long-term } \\
\hline 1. Gender & - & & & & & & & & & 1.50 & .501 & \\
\hline 2. Age & $.214^{* *}$ & - & & & & & & & & 1.51 & .684 & \\
\hline $\begin{array}{l}\text { 3. Destination-loyalty } \\
\text { intention }\end{array}$ & .032 & .026 & - & & & & & & & 4.06 & .757 & .62 \\
\hline $\begin{array}{l}\text { 4. Orientation to } \\
\text { heritage culture }\end{array}$ & .013 & -.071 & $.205^{* *}$ & - & & & & & & 3.92 & .433 & .73 \\
\hline $\begin{array}{l}\text { 5. Orientation to } \\
\text { mainstream culture }\end{array}$ & -.072 & $-.224^{* *}$ & $.334^{* *}$ & .117 & - & & & & & 3.54 & .462 & .74 \\
\hline $\begin{array}{l}\text { 6. Psychological } \\
\text { adaptation }\end{array}$ & $-.174^{*}$ & $-.197^{* *}$ & $.176^{\circ}$ & $.222^{* *}$ & $.358^{* *}$ & - & & & & 3.52 & .698 & .76 \\
\hline $\begin{array}{l}\text { 7. Sociocultural } \\
\text { adaptation }\end{array}$ & -.048 & -.094 & $.212^{* *}$ & -.018 & $.228^{* *}$ & $.226^{* *}$ & - & & & 3.50 & .675 & .91 \\
\hline $\begin{array}{l}\text { 8. Destination } \\
\text { motivation (Push) }\end{array}$ & $.205^{* *}$ & -.014 & $.179^{\circ}$ & $.213^{* *}$ & .108 & .016 & $-.155^{\circ}$ & - & & 3.63 & .854 & .70 \\
\hline $\begin{array}{l}\text { 9. Destination } \\
\text { motivation (Pull) }\end{array}$ & .091 & .049 & $.280^{\circ *}$ & .087 & .097 & .010 & $-.199^{* *}$ & $.371^{* *}$ & - & 3.30 & .533 & .74 \\
\hline
\end{tabular}


Table 3: Summary of Hierarchical Regression Analysis for Variables predicting Destination-Loyalty Intention

\begin{tabular}{|c|c|c|c|c|c|c|c|c|c|}
\hline & & $\beta$ & Sig. & Tolerance & VIF & $\mathrm{R}$ & R Square & $\begin{array}{c}\Delta \mathrm{R} \\
\text { Square }\end{array}$ & Durbin-Watson \\
\hline \multicolumn{10}{|c|}{ Short-term } \\
\hline \multirow[t]{3}{*}{1} & (Constant) & & .000 & & & $.141^{\mathrm{a}}$ & .020 & .020 & 2.18 \\
\hline & Gender & -.14 & .069 & .996 & 1.00 & & & & \\
\hline & Age & .05 & .509 & .996 & 1.00 & & & & \\
\hline \multirow[t]{5}{*}{2} & (Constant) & & .000 & & & $.225^{b}$ & .051 & .031 & \\
\hline & Gender & -.12 & .094 & .983 & 1.02 & & & & \\
\hline & Age & .03 & .665 & .987 & 1.01 & & & & \\
\hline & $\begin{array}{l}\text { Destination } \\
\text { motivation (Push) }\end{array}$ & .00 & .976 & .764 & 1.31 & & & & \\
\hline & $\begin{array}{l}\text { Destination } \\
\text { motivation (Pull) }\end{array}$ & $.18^{*}$ & .037 & .766 & 1.31 & & & & \\
\hline \multirow[t]{9}{*}{3} & (Constant) & & .001 & & & $.498^{c}$ & .248 & .197 & \\
\hline & Gender & -.11 & .095 & .959 & 1.04 & & & & \\
\hline & Age & .00 & .929 & .978 & 1.02 & & & & \\
\hline & $\begin{array}{l}\text { Destination } \\
\text { motivation (Push) }\end{array}$ & -.02 & .752 & .757 & 1.32 & & & & \\
\hline & $\begin{array}{l}\text { Destination } \\
\text { motivation (Pull) }\end{array}$ & $.16^{*}$ & .041 & .713 & 1.40 & & & & \\
\hline & $\begin{array}{l}\text { Orientation to } \\
\text { heritage culture }\end{array}$ & $-.24 * *$ & .002 & .729 & 1.37 & & & & \\
\hline & $\begin{array}{l}\text { Orientation to } \\
\text { mainstream culture }\end{array}$ & $.43^{* * *}$ & .000 & .670 & 1.49 & & & & \\
\hline & $\begin{array}{l}\text { Psychological } \\
\text { adaptation }\end{array}$ & $.16^{*}$ & .024 & .855 & 1.17 & & & & \\
\hline & $\begin{array}{l}\text { Sociocultural } \\
\text { adaptation }\end{array}$ & .06 & .375 & .931 & 1.07 & & & & \\
\hline \multicolumn{10}{|c|}{ Long-term } \\
\hline \multirow[t]{3}{*}{1} & (Constant) & & .000 & & & $.037^{\mathrm{a}}$ & .001 & .001 & 1.97 \\
\hline & Gender & .03 & .708 & .954 & 1.05 & & & & \\
\hline & Age & .02 & .789 & .954 & 1.05 & & & & \\
\hline \multirow[t]{5}{*}{2} & (Constant) & & .000 & & & $.292^{b}$ & .085 & .084 & \\
\hline & Gender & -.01 & .862 & .911 & 1.10 & & & & \\
\hline & Age & .02 & .806 & .948 & 1.06 & & & & \\
\hline & $\begin{array}{l}\text { Destination } \\
\text { motivation (Push) }\end{array}$ & .09 & .242 & .828 & 1.21 & & & & \\
\hline & $\begin{array}{l}\text { Destination } \\
\text { motivation (Pull) }\end{array}$ & $.25 * *$ & .001 & .859 & 1.16 & & & & \\
\hline \multirow[t]{9}{*}{3} & (Constant) & & .168 & & & $.501^{\mathrm{c}}$ & .251 & .165 & \\
\hline & Gender & .00 & .947 & .890 & 1.12 & & & & \\
\hline & Age & .11 & .121 & .895 & 1.12 & & & & \\
\hline & $\begin{array}{l}\text { Destination } \\
\text { motivation (Push) }\end{array}$ & .06 & .415 & .784 & 1.28 & & & & \\
\hline & $\begin{array}{l}\text { Destination } \\
\text { motivation (Pull) }\end{array}$ & $.26 * * *$ & .000 & .828 & 1.21 & & & & \\
\hline & $\begin{array}{l}\text { Orientation to } \\
\text { heritage culture }\end{array}$ & $.15^{*}$ & .029 & .904 & 1.11 & & & & \\
\hline & $\begin{array}{l}\text { Orientation to } \\
\text { mainstream culture }\end{array}$ & $.25 * *$ & .001 & .801 & 1.25 & & & & \\
\hline & $\begin{array}{l}\text { Psychological } \\
\text { adaptation }\end{array}$ & .02 & .768 & .787 & 1.27 & & & & \\
\hline & $\begin{array}{l}\text { Sociocultural } \\
\text { adaptation }\end{array}$ & $.22^{* *}$ & .001 & .862 & 1.16 & & & & \\
\hline
\end{tabular}

To summarize, results for short-term students showed that Hypotheses 2a, 4a, and 6a, namely destination motivation (pull) $(b=0.16, p$ $<.05)$, orientation to mainstream culture $(b=0.43, p<.001)$ and 
psychological adaptation $(b=0.16, p<.05)$, contributed more to the explained variance in destination-loyalty intention than orientation to heritage culture (Hypothesis 3a) $(b=-0.24, p<.01)$. For long-term students, results also showed that Hypotheses $2 \mathrm{~b}, 4 \mathrm{~b}$ and $5 \mathrm{~b}$, namely destination motivation (pull) $(b=0.26, p<.001)$, orientation to mainstream culture $(b=0.25, p<.01)$, and sociocultural adaptation $(b=0.22, p<.01)$, made a greater contribution to the explained variance than orientation to heritage culture (Hypothesis $5 b)(b=0.15, p<.05)$ in influencing destination-loyalty intention. However, between the two groups, only destination motivation (pull) shows a stronger relationship with destinationloyalty intention for long-term students as compared to short-term students.

\section{DISCUSSION}

The overall working hypothesis of this study was that international students can influence friends, family members or other people in their social network to visit the country in which they have studied, and that the findings may have some ramifications for the international student exchange programs, and also for the tourist industry of the country concerned.

Results suggested that gender and age did not contribute significantly to the regression model, neither for short-term nor long-term students. The most important predictors of destination-loyalty intention for both short-term and long-term students were destination motivation (pull), orientation to heritage and orientation to mainstream culture. Of the two forms of adaptation, sociocultural adaptation was found to be related to destination-loyalty intention only for long-term students. Psychological adaptation was significant in predicting destination-loyalty intention only among short-term students.

Our findings concerning Hypothesis 1, on whether international students' destination motivation (push) will have weaker relationship with destination-loyalty intention for (H1a) short-term than (H1b) long-term students indicated that destination motivation (push) for both short-term and long-term students was not consistent with the hypothesis. The association between push motivation and destination-loyalty intention is a bit puzzling. The results did not show significant associations between push motivation and destination-loyalty intention. The researchers speculate that perhaps, for international students, destination motivation (push) might offer considerable power in predicting and explaining participation in destinationloyalty intention at the initial stage prior to the actual international education experiences. The researchers believe that in this study, in which the students 
are already at the destination, other factors relating to social and academic life may be more important when trying to navigate successfully in the new environment (see Sam, Tetteh, \& Amponsah, 2015).

Hypothesis 2 on positive association between international students' destination motivation (pull) destination-loyalty intention was supported for both short-term (H2a) and long-term (H2b) students. However, between the two, destination motivation (pull) shows a stronger relationship with destination-loyalty intention for long-term students as compared to shortterm students. This results supports suggestions by Dwyer (2004) on the stronger impact of study abroad on long-term students than their short-term counterparts. These findings is in line with suggestions by Mazzarol and Soutar (2002) that destination motivation (pull) is more important to promote a destination. This is because many countries are presently "upgrading" their supply side of international education. The "upgrading" includes host country institutions developing branch campuses in other countries that will gradually reduce the impact of the push factor (Mazzarol \& Soutar, 2002). Under these circumstances, the researchers posit that the host countries' ability to continue to remain competitive in attracting foreign students will depend mostly on pull motivation factors. Of these, the researchers found that knowledge and awareness, reputation, social cost issues, and social links are likely to be important for international students. This is not surprising but further highlights the need for host country governments and education institutions to increase investment in organizational substructures that are likely to impact on these student values, ensuring that promotion activities are implemented effectively.

Moreover, results from the hierarchical analyses on temporal changes that occur between international students' destination motivations (short-term and long-term) show that in international education, students adopt fairly stable motivations during their international sojourn. The results of this investigation strongly support the effectiveness of destination motivation (pull) as a variable for predicting and understanding destinationloyalty intention. The researchers believe that, even though motivation can fluctuate (Darby, Longmire-Avital, Chenault, \& Haglund, 2013; Kiemer, Gröschner, Pehmer, \& Seidel, 2015), international students' destination motivation (pull) experience may offer considerable power with regard to their intentions to recommend the destination to others and to revisit.

A negative relationship was found between short-term international students' orientation to heritage culture (Hypothesis 3a) and destinationloyalty intention. Perhaps this relationship can be explained in the context of international students' unmet expectations. This is in line with Berry (2005), 
who suggested that individuals who place a value on holding on to their heritage culture tend to turn their back on involvement with other cultural groups while holding on to their heritage culture. The researchers posit this negatively influences destination-loyalty intention. Consequently, Pitts (2009) has proposed that a pre-departure training program that includes information on how to recognize and manage external expectations is important. Pre-departure training may not only help students develop realistic expectations and goals regarding the overseas sojourn, it may also enhance their chances of "succeeding" and subsequently their destinationloyalty intention.

With respect to long-term students, a positive relationship was found between students' orientation to heritage culture and destinationloyalty intention (Hypothesis $3 b$ ). This was not consistent with hypothesis $3 \mathrm{~b}$. However, this finding supports the suggestion by Berry (2005) that most people undergoing acculturation adjust positively. Further, Berry (1997) proposed that orientation to heritage culture is part of the integration acculturation strategy. Several studies have found a positive relationship between integration and adaptation (Hui, Chen, Leung, \& Berry, 2015). Evidence suggested that international students are not substantially demotivated by their orientation to heritage culture. The researchers posit that possibly the nature of their stay (education) influences them. They find opportunities, and manage to navigate in the new society to achieve their goals, sometimes beyond their expectations. The argument and evidence presented here relate primarily to long-term international students. However, they are equally relevant for institutional arrangements, industry players and for individuals in the wider society. Nevertheless, in the absence of conceptual clarity and empirical foundations, further research is essential to clarify these mixed results for both groups of international students.

Hypotheses $4 \mathrm{a}$ and $4 \mathrm{~b}$ supported the notion that orientation to mainstream culture is positively related to destination-loyalty intention. However, between the two groups, the researchers found that the effect of orientation to mainstream culture on destination-loyalty intention was stronger among short-term students than long term students. This is not in line with suggestions by Dwyer (2004) and Hypothesis 4. However, the findings are consistent with past research that show a positive association between orientation to mainstream culture and destination-loyalty intention (Jamaludin et al., 2016a; Zea et al., 1997). These two studies suggest that well-adjusted students in the host communities are more likely to remain and have a sense of positive integration or assimilation, which arguably should strengthen their educational goals, commitment and loyalty. Thus, 
international students who have a positive experience and strong relationship with the host society are more likely to return to the host destination or recommend it to others. Based on the results, the researchers believe industry players need to accentuate the international students' experiences at their destination. The researchers recommend that the institutions of higher learning come up with programs that increase the degree of social participation for international students. Future researchers should continue to conduct systematic investigations of this factor in order to better attract and retain international students. The researchers contend that this work has the potential to advance the development of culturally informed, empirically supported interventions for international students.

Our results indicated that sociocultural adaptation has a positive influence on destination-loyalty intention only for long-term students, and not short-term students. According to Sam et al. (2015), individuals who perceive themselves to be socially skilled also feel confident in their understanding of the culture of the new society. Berry (2005) found a linear relationship between sociocultural adaptation and time. Thus, our finding with respect to long-term students compared to short-term students seems reasonable.

Language proficiency, communication competence, and effective social interaction are three major keys to sociocultural adaptation (Searle \& Ward, 1990; Ward \& Rana-Deuba, 1999). Within this context, the researchers believe that enhancing Norwegian language skills will be a major breakthrough. Industry players and educational institutions should come up with programs that are directly related to increased interaction with host nationals, giving a consequent decrease in sociocultural adjustment problems. It could result in better intercultural understanding and diminished feelings of strangeness and social distance. Furthermore, the researchers believe that intercultural training may be effective in facilitating a student's adjustment in the foreign country.

Finally, the findings for Hypothesis 6 indicate that psychological adaptation was related to destination-loyalty intention only for short-term students. It is possible that short-term students, whose academic degrees are conferred by their home institution, can afford to take life with ease as they collect a few course credits (Sam et al., 2015), unlike long-term students taking a full academic degree at a foreign university. Short-term students are also known to spend a lot of time sightseeing and touring during their overseas sojourn (Sam et al., 2015). It is plausible that their overall satisfaction is related to the joys of touring and sightseeing; thus, this will influence their intention to revisit and recommend the destination. 
Further, all of the short-term students in this study originated from Europe, and can travel back to their home countries for a brief period, even for a weekend if they want. This perhaps further influences their psychological adaptation and subsequently their destination-loyalty intention.

Our analyses of how orientation to heritage culture and adaptation affects destination-loyalty intention reveal a generally reliable pattern. Nevertheless, the inconsistent findings with hypotheses require further verification.

\section{LIMITATIONS AND RECOMMENDATIONS}

A natural question is whether our findings can be generalized to other international students in other Western countries. The researchers think it is too early to give a clear answer to this question, except to suggest that more studies are needed. The researchers recommend that future studies should use more heterogeneous samples, such as international students from other places. Destination-loyalty intentions in this study were measured during the international students' stay in Norway. The researchers do not know whether these results would be maintained when the students return to their home countries. However, the researchers believe, research examining destination-loyalty intentions after completion of the students' overseas sojourn will go a long way in providing us with a better understanding of this phenomenon.

The researchers postulate that these findings can be developed further to offer new insights into research on destination-loyalty intention beyond perceiving destination motivation, cultural orientation, and adaptation solely as predictors. Although each of these findings represents an important contribution to the understanding of student loyalty intention, a significant amount of research is still required in order to explicate relational exchanges in this context, given the competitive context in which they are presently immersed.

\section{CONCLUSION}

It can be concluded that for short-term students, destination motivation (pull) together with orientation to mainstream, orientation to heritage and psychological adaptations are the most important variables in influencing international students' decision to revisit and recommend the destination. For long-term students, destination motivation (pull) together with 
orientation to mainstream, orientation to heritage, and sociocultural adaptations are the most important variables in destination-loyalty intention.

The researchers argue that the current study provides some insights into the potential for destination motivation, cultural orientation, and adaptation in influencing destination-loyalty intention in international education experiences. This approach could be developed further to offer new insights into research on destination-loyalty intention beyond seeing destination motivation, cultural orientation, and adaptation as predictors. However, the researchers believe much more research is needed in order to explain relational exchanges in this context, given the present competitive context in which they are now immersed. Despite the exploratory nature of this study, the findings add insights to the psychology of international students and improve knowledge about destination-loyalty intention.

\section{REFERENCES}

Ajzen, I., \& Madden, T. J. (1986). Prediction of goal-directed behavior: Attitudes, intentions, and perceived behavioral control. Journal of experimental social psychology, 22(5), 453-474.

Berry, J. W. (1990). Psychology of acculturation. In J. Berman (Ed.), Cross-cultural perspective. Nebraska Symposium on Motivation (Vol. 37, pp. 201-234). Lincoln: University of Nebraska Press.

Berry, J. W. (1992). Acculturation and adaptation in a new society. International Migration, 30(1/2).

Berry, J. W. (1997). Immigration, acculturation, and adaptation. Applied Psychology, 46(1), 5-34. doi: 10.1111/j.1464-0597.1997.tb01087.x

Berry, J. W. (2005). Acculturation: Living successfully in two cultures. International Journal of Intercultural Relations, 29(6), 697-712.

Berry, J. W., Kim, U., Minde, T., \& Mok, D. (1987). Comparative studies of acculturative stress. International Migration Review, 21, 491-511.

Berry, J. W., Kim, U., Power, S., Young, M., \& Bujaki, M. (1989). Acculturation attitudes in plural societies. Applied Psychology, 38(2), 185-206.

Berry, J. W., Phinney, J. S., Sam, D. L., \& Vedder, P. (2006). Immigrant youth in cultural transition: Acculturation, identity and adaptation across national context. Mahwah, NJ.. Lawrence Erlbaum.

Berry, J. W., \& Sam, D. L. (1997). Acculturation and adaptation. Handbook of cross-cultural psychology (Vol. 3, pp. 291-326). Boston: Allyn \& Bacon.

Berry, J. W., \& Sam, D. L. (2003). Accuracy in scientific discourse. Scandinavian Journal of Psychology, 44(1), 65-68. doi: 10.1111/1467-9450.00322

Bieger, T., \& Laesser, C. (2002). Market segmentation by motivation: The case of Switzerland. Journal of Travel Research, 41(1), 68-76. 
Brewer, E. (1983). Motivation for International Exchange. Paper presented at the 35th Annual Conference of the National Association for Foreign Student Affairs, Cincinnati, $\mathrm{OH}$.

Campbell, N. (2011). Promoting intercultural contact on campus: A project to connect and engage international and host students. Journal of Studies in International Education, 16(3), 205-227.

Carlson, J. S., \& Widaman, K. F. (1988). The effects of study abroad during college on attitudes toward other cultures. International Journal of Intercultural Relations, 12(1), 1-17.

Caudery, T., Petersen, M., \& Shaw, P. (2008). The motivations of exchange students at Scandinavian universities. In M. Byram \& F. Dervin (Eds.), Students, staff and academic mobility in higher education (pp. 114-130). Newcastle: Cambridge Scholars Press.

Chen, C.-F., \& Tsai, D. (2007). How destination image and evaluative factors affect behavioral intentions? Tourism Management, 28(4), 1115-1122.

Dann, G. M. S. (1977). Anomie, ego-enhancement and tourism. Annals of Tourism Research, 4(4), 184-194. doi: 10.1016/0160-7383(77)90037-8

Dann, G. M. S. (1981). Tourist motivation an appraisal. Annals of Tourism Research, 8(2), 187-219. doi: 10.1016/0160-7383(81)90082-7

Darby, A., Longmire-Avital, B., Chenault, J., \& Haglund, M. (2013). Students' motivation in academic service-learning over the course of the semester. College Student Journal, 47(1), 185-191.

Deci, E. L., \& Ryan, R. M. (2000). The "what" and" why" of goal pursuits: Human needs and the self-determination of behavior. Psychological inquiry, 11(4), 227-268.

Diener, E., Emmons, R. A., Larsen, R. J., \& Griffin, S. (1985). The Satisfaction with Life Scale. Journal of Personality Assessment, 49(1), 71-75. doi: 10.1207/s15327752jpa4901_13

Diener, E., Kanazawa, S., Suh, E. M., \& Oishi, S. (2015). Why people are in a generally good mood. Personality and Social Psychology Review, 19(3), 235-256.

Dorozhkin, I. N., \& Mazitova, L. T. (2008). Problems of the social adaptation of foreign college students. Russian Education \& Society, 50(2), 23-30.

Dwyer, M. M. (2004). More is better: The impact of study abroad program duration. Frontiers, 10, 151-163.

Faber, R. J., O'Guinn, T. C., \& Meyer, T. P. (1987). Televised portrayals of Hispanics: A comparison of ethnic perceptions. International Journal of Intercultural Relations, 11(2), 155-169.

Furnham, A. F., \& Bochner, S. (1982). Social difficulty in a foreign culture: An empirical analysis of culture shock. In S. Bochner (Ed.), Cultures in contact: Studies in cross-cultural interaction (pp. 161-198). Oxford, England: Pergamon. 
George, B. P., \& George, B. P. (2012). Past visits and the intention to revisit a destination: Place attachment as the mediator and novelty seeking as the moderator. Journal of Tourism Studies, 15(2), 37-50.

González, C. R., Mesanza, R. B., \& Mariel, P. (2011). The determinants of international student mobility flows: an empirical study on the Erasmus programme. Journal of Higher Education, 62(4), 413-430.

Graham, C., \& Markowitz, J. (2011). Aspirations and happiness of potential Latin American immigrants. Journal of Social Research and Policy, 2(2), 9-25.

Guo, S., \& Chase, M. (2011). Internationalisation of higher education: Integrating international students into Canadian academic environment. Teaching in Higher Education, 16(3), 305-318.

Hair, J. F., Black, W. C., Babin, B. J., \& Anderson, R. E. (2010). Multivariate data analysis: A global perspective (7th ed.). Upper Saddle River, NJ: Prentice Hall.

Hill, A. P. (2013). Motivation and university experience in first-year university students: A self-determination theory perspective. Journal of Hospitality, Leisure, Sport \& Tourism Education, 13, 244-254.

Hirai, R., Frazier, P., \& Syed, M. (2015). Psychological and sociocultural adjustment of first-year international students: Trajectories and predictors. Journal of Counseling Psychology, 62(3), 438.

Hui, B. P. H., Chen, S. X., Leung, C. M., \& Berry, J. W. (2015). Facilitating adaptation and intercultural contact: The role of integration and multicultural ideology in dominant and non-dominant groups. International Journal of Intercultural Relations, 45, 70-84.

Jamaludin, N. L., Sam, D. L., Sandal, G. M., \& Adam, A. A. (2016a). The influence of perceived discrimination, orientation to mainstream culture and life satisfaction on destination loyalty intentions: the case of international students. Current Issues in Tourism, 1-16.

Jamaludin, N. L., Sam, D. L., Sandal, G. M., \& Adam, A. A. (2016b). Personal values, subjective well-being and destination-loyalty intention of international students. SpringerPlus. doi: 10.1186/s40064-016-2439-3

Jang, S., \& Cai, L. A. (2002). Travel motivations and destination choice: A study of British outbound market. Journal of Travel \& Tourism Marketing, 13(3), 111-133.

Kember, D., Hong, C., \& Ho, A. (2008). Characterizing the motivational orientation of students in higher education: A naturalistic study in three Hong Kong universities. British Journal of Educational Psychology, 78(2), 313-329.

Kiemer, K., Gröschner, A., Pehmer, A.-K., \& Seidel, T. (2015). Effects of a classroom discourse intervention on teachers' practice and students' motivation to learn mathematics and science. Learning and Instruction, 35, 94-103.

Kim, K. (2008). Analysis of structural equation model for the student pleasure travel market: Motivation, involvement, satisfaction, and destination loyalty. Journal of Travel \& Tourism Marketing, 24(4), 297-313. 
Kim, S.-S., \& Lee, C.-K. (2002). Push and pull relationships. Annals of Tourism Research, 29(1), 257-260.

Lee, C. C., Backman, K., \& Backman, S. (1987, 1997). Understanding antecedents of repeat visitation and tourists' loyalty to a resort destination. Paper presented at the Travel and Tourism Research Association Annual Conference, TTRA, Boulder, CO.

Lee, J. S. (2002). The Korean language in America: The role of cultural identity in heritage language learning. Language Culture and Curriculum, 15(2), $117-133$.

Lee, T. H. (2009). A structural model to examine how destination image, attitude, and motivation affect the future behavior of tourists. Leisure Sciences, 31(3), 215-236.

Lesjak, M., Juvan, E., Ineson, E. M., Yap, M. H. T., \& Axelsson, E. P. (2015). Erasmus student motivation: Why and where to go? Higher Education, 121.

Lu, C. Y., Yeh, W.-J., \& Chen, B. T. (2016). The study of international students' behavior intention for leisure participation: Using perceived risk as a moderator. Journal of Quality Assurance in Hospitality \& Tourism, 17(2), 224-236.

Mahmood, H. (2014). An analysis of acculturative stress, sociocultural adaptation, and satisfaction among international students at a non-metropolitan university (Doctoral dissertation). Western Kentucky University, Bowling Green, Kentucky.

Massey, J., \& Burrow, J. (2012). Coming to Canada to study factors that influence students decisions to participate in international exchange. Journal of Student Affairs Research and Practice, 49(1), 83-100.

Mazzarol, T., \& Soutar, G. N. (2002). "Push-pull” factors influencing international student destination choice. International Journal of Educational Management, 16(2), 82-90.

Neblett, E. W., Rivas-Drake, D., \& Umaña-Taylor, A. J. (2012). The promise of racial and ethnic protective factors in promoting ethnic minority youth development. Child Development Perspectives, 6(3), 295-303.

Oppermann, M. (2000). Tourism destination loyalty. Journal of Travel Research, 39(1), 78-84.

Otrachshenko, V., \& Popova, O. (2014). Life (dis) satisfaction and the intention to migrate: Evidence from Central and Eastern Europe. The Journal of SocioEconomics, 48, 40-49.

Pallant, J. (2013). SPSS survival manual (5th ed.). New York: McGraw-Hill.

Pitts, M. J. (2009). Identity and the role of expectations, stress, and talk in shortterm student sojourner adjustment: An application of the integrative theory of communication and cross-cultural adaptation. International Journal of Intercultural Relations, 33(6), 450-462.

Ryan, C., \& Glendon, I. (1998). Application of leisure motivation scale to tourism. Annals of Tourism Research, 25(1), 169-184. 
Ryder, A. G., Alden, L. E., \& Paulhus, D. L. (2000). Is acculturation unidimensional or bidimensional? A head-to-head comparison in the prediction of personality, self-identity, and adjustment. Journal of Personality and Social Psychology, 79(1), 49-65.

Sam, D. L., \& Berry, J. W. (2010). Acculturation: When individuals and groups of different cultural backgrounds meet. Perspectives on Psychological Science, 5(4), 472-481. doi: 10.1177/1745691610373075

Sam, D. L., Tetteh, D. K., \& Amponsah, B. (2015). Satisfaction with life and psychological symptoms among international students in Ghana and their correlates. International Journal of Intercultural Relations, 49, 156-167.

Sánchez, C. M., Fornerino, M., \& Zhang, M. (2006). Motivations and the intent to study abroad among US, French, and Chinese students. Journal of Teaching in International Business, 18(1), 27-52.

Schachner, M. K., Schiller, F., Van de Vijver, F. J. R., \& Noack, P. (2014). Characteristics of the country of origin and immigrant children's psychological and sociocultural school adjustment. Toward sustainable development through nurturing (or appreciating) diversity. Retrieved from http//: www. iaccp. org/drupal/ebooks.

Searle, W., \& Ward, C. (1990). The prediction of psychological and sociocultural adjustment during cross-cultural transitions. International Journal of Intercultural Relations, 14(4), 449-464.

Shigaki, I. S., \& Smith, S. A. (1997). A cultural sharing model: American buddies for international students. International Education, 27(1), 5-21.

Shin, D. C., \& Johnson, D. M. (1978). Avowed happiness as an overall assessment of quality of life. Social Indicators Research, 5(4), 475-492. doi: 10.1007/Bf00352944

Sirakaya, E., Uysal, M., \& Yoshioka, C. F. (2003). Segmenting the Japanese tour market to Turkey. Journal of Travel Research, 41(3), 293-304.

Soderlund, M., \& Ohman, N. (2003). Behavioral intentions in satisfaction research revisited. Journal of Consumer Satisfaction Dissatisfaction and Complaining Behavior, 16, 53-66.

Souto-Otero, M., Huisman, J., Beerkens, M., de Wit, H., \& VujiĆ, S. (2013). Barriers to international student mobility evidence from the Erasmus program. Educational Researcher, 42(2), 70-77.

Stone, C. (2000). The SOS program (Students for Other Students): A student mentor program. Journal of the Australian and New Zealand Student Services Association, 16, 55-74.

Tabachnick, B. G., \& Fidell, L. S. (2001). Using multivariate statistics. Boston: Allyn \& Bacon

Toyokawa, T., \& Toyokawa, N. (2002). Extracurricular activities and the adjustment of Asian international students: A study of Japanese students. International Journal of Intercultural Relations, 26(4), 363-379. doi: 10.1016/S0147-1767(02)00010-X 
Vedder, P., van de Vijver, F. J. R., \& Liebkind, K. (2006). Predicting immigrant youth's adaptation across countries and ethnocultural groups Immigrant youth in cultural transition: Acculturation, identity and adaptation across national contexts (pp. 143-166). London: Lawrence Erlbaum.

Wang, C.-C. D. C., \& Mallinckrodt, B. (2006). Acculturation, attachment, and psychosocial adjustment of Chinese/Taiwanese international students. Journal of Counseling Psychology, 53(4), 422-433.

Wang, Q., \& Hannes, K. (2014). Academic and socio-cultural adjustment among Asian international students in the Flemish community of Belgium: A photovoice project. International Journal of Intercultural Relations, 39, 66-81.

Wang, X., \& Leou, C. H. (2015). A study of tourism motivation, perceived value and destination loyalty for Macao cultural and heritage tourists. International Journal of Marketing Studies, 7(6), 83-91.

Ward, C. (1996). Acculturation. In D. Landis \& R. Bhagat (Eds.), Handbook of intercultural training (2nd ed., pp. 124-147). Thousand Oaks, CA: Sage.

Ward, C. (2001). The A, B, Cs of acculturation. In D. Matsumoto (Ed.), The handbook of culture and psychology (pp. 411-445). Oxford, UK: Oxford University Press.

Ward, C., \& Kennedy, A. (1999). The measurement of sociocultural adaptation. International Journal of Intercultural Relations, 23(4), 659-677.

Ward, C., \& Rana-Deuba, A. (1999). Acculturation and adaptation revisited. Journal of Cross-Cultural Psychology, 30(4), 422-442.

Yavas, U. (1990). Correlates of vacation travel: some impirical evidence. Journal of Professional Services Marketing, 5(2), 3-18.

Yoon, Y., \& Uysal, M. (2005). An examination of the effects of motivation and satisfaction on destination loyalty: A structural model. Tourism Management, 26(1), 45-56. doi: 10.1016/j.tourman.2003.08.016

Yuksel, A., Yuksel, F., \& Bilim, Y. (2010). Destination attachment: Effects on customer satisfaction and cognitive, affective and conative loyalty. Tourism Management, 31(2), 274-284. doi: 10.1016/j.tourman.2009. 03.007

Zea, M. C., Reisen, C. A., Beil, C., \& Caplan, R. D. (1997). Predicting intention to remain in college among ethnic minority and nonminority students. The Journal of Social Psychology, 137(2), 149-160.

Zhang, N., \& Dixon, D. N. (2003). Acculturation and attitudes of Asian international students toward seeking psychological help. Journal of Multicultural Counseling and Development, 31(3), 205-222.

NOR LELAWATI JAMALUDIN received her PhD from University of Bergen, Norway and is a senior lecturer at Universiti Teknologi MARA, Selangor, Malaysia. Email: norlelawati0019@salam.uitm.edu.my 
DAVID LACKLAND SAM, $\mathrm{PhD}$, is a professor of cross-cultural psychology at University of Bergen, Norway. Email: david.sam@ psysp.uib.no

GRO MJELDHEIM SANDAL, PhD, is a professor in psychology at University of Bergen, Norway. Email: gro.sandal@psysp.uib.no 